\section{Fedme, livsstilssykdommer og karbohydrater}

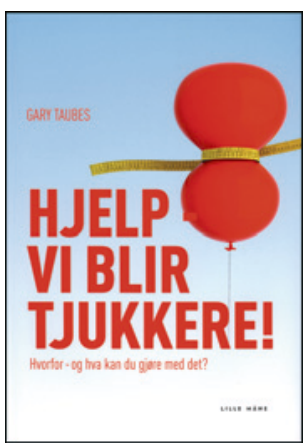

Gary Taubes

Hjelp - vi blir tjukkere!

Hvorfor - og hva kan du gjøre med det? 235 s, ill. Oslo: Forlaget Lille Måne 2012.

Pris NOK 349 (E-bok NOK 159)

ISBN 978-82-93154-55-6

Gary Taubes er en prisbelønnet amerikansk vitenskaps- og forskningsjournalist. Han har i en årrekke skrevet for magasinet Science, men har også publisert en rekke andre artikler, blant annet i New York Times og BMJ. De senere årene har kosthold og fedme gjennomgående vært hans hovedtema.

Hjelp - vi blir tjukkere er på mange måter en mer lettlest og kortere versjon av Taubes egen Good Calories, Bad Calories fra 2007 - en bok hvor han over 609 tettskrevne sider, rike på detaljer og referanser, tok et oppgjør med den moderne ernæringsforskningen og dens konklusjoner. Eller som forfatteren selv skriver i forordet: «Jeg kommer her med argumentene mot den konvensjonelle kunnskapen, kokt ned til sin essens.»

I den første delen tar han et oppgjør med «kalorier inn - kalorier ut»- hypotesen. Her drøfter Taubes det han mener er observasjoner og uunngåelige fakta denne hypotesen ikke kan forklare, og hvordan termodynamikkens lover ikke gir oss noe svar på hvorfor vi tar inn flere kalorier enn det vi forbruker. De sier bare at vi blir tyngre dersom vi gjør det.

I den andre delen drøfter forfatteren tankesettet og hypotesene rundt overvekt og fedme. Her forteller han hvordan overvektens metabolisme får den overvektige til å spise mer. Barn for eksempel, argumenterer Taubes, vokser ikke fordi de er glupske og spiser for mye, de spiser mer fordi hormonelle stimuli gjør at de vokser. Slik er det også med overvektige, hormonelle stimuli gjør at de spiser for mye fordi de legger på seg - ikke omvendt.

Taubes teori går i korthet ut på at nøkkelen til å forstå fedme, hvordan den oppstår og hvordan den kan forebygges, ligger i insulinets dominerende rolle i reguleringen av fettvevet. Høye nivåer av insulin blokkerer fettforbrenning - og dermed organismens tilgang til kroppens energilager nummer én, mens lavere verdier opprettholder kroppens bruk av fettsyrer som energikilde. Taubes mener at mat som stimulerer til høy insulinutskilling forstyrrer energibalansen, og fører til økt sult og dermed høyere næringsinntak. Skal man forbli slank eller gå ned i vekt, må denne maten unngås: «Flytende karbohydrater som øl, juice og brus er trolig verst.»

Dette er et interessant og lettlest innlegg i en pågående internasjonal kostholdsdebatt. For mange vil det være provokativt, og Taubes tar nok også noen akademiske snarveier i sin argumentasjon. I noen sammenhenger blir eksempelvis statistiske assosiasjoner til kausalitet - og hvor ble det av leptin og fruktose? Like fullt er boken både leseverdig og underholdende og kan anbefales til alle ernæringsinteresserte med et åpent sinn.

\section{God norsk oppsummering av kunnskapsstatus om angstlidelser}

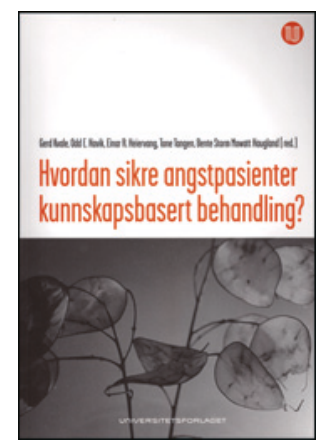

\author{
Gerd Kvale, Odd E. Havik, \\ Einar R. Heiervang et al, red. \\ Hvordan sikre angstpasienter \\ kunnskapsbasert behandling?
}

226 s, tab, ill. Oslo: Universitetsforlaget, 2013.

Pris NOK 329

ISBN 978-82-15-01879-9

En rekke fagfolk bidrar i denne boken, som har sitt utspring i presentasjoner holdt på en konferanse i desember 2010, arrangert av Regionalt forskningsnettverk for angstlidelser, Helse Vest. Ambisjonen er å beskrive forskningsbasert viten om diagnostikk og behandling av angstlidelser ut fra en kognitiv atferdsterapeutisk modell, i tillegg til å belyse hvordan man best sikrer at kunnskapen blir implementert i klinisk praksis.

De 19 kapitlene er oppdelt i fire bolker. I de fem første kapitlene gir forfatterne en generell innføring i angstlidelsenes epidemiologi, helsemyndighetenes planer og evidensgrunnlaget for kognitiv atferdsterapi ved angstlidelser. De neste sju kapitlene omhandler behandling av angstlidelser hos voksne. Kognitiv atferdsterapi ved panikklidelse, sosial angstlidelse, tvangslidelser og odontofobi beskrives. Også veiledet selvhjelp, fysisk aktivitet som behandling og «mindfulness»-baserte intervensjoner er viet egne kapitler. Bolken avsluttes med et interessant kapittel om betydningen av såkalte spesifikke faktorer ved behandling av angstlidelser.

I den neste bolken, kapitlene 13 til 16, beskrives kunnskapsbasert behandling av barn og unge med angstlidelser, eksemplifisert med beskrivelser av lavterskeltilbud, behandling av tvangslidelser og selektiv mutisme. De siste tre kapitlene er viet brukererfaringer fra henholdsvis lavterskeltilbud for voksne, barne- og ungdomspsykiatrien (BUP) og poliklinisk behandling av tvangslidelse hos en voksen mann.

Angstlidelser er blant de mest utbredte og kostbare lidelsene for samfunnet. I løpet av de siste tiårene er ny kunnskap generert og mer effektiv behandling utviklet. Forfatterne gir en bred og god innføring i temaet. Misforholdet mellom kunnskapsstatus og det reelle behandlingstilbudet drøftes, og tiltak for å rette på dette, som bl.a. oppbygging av OCD-team og lavterskeltilbud, beskrives. Stoffet er ryddig presentert. Klinikere, helseadministratorer på forskjellige nivåer og interesserte legfolk vil finne boken lærerik.

\section{Bjørn Ravneberg}

Oslo 